\title{
13
}

\section{The impact of urbanisation on economic growth}

\section{Xiaolu Wang and Ronald Duncan}

With only 0.3 hectares of arable land per farmer, China's agriculture has successfully fed its 1.2 billion people. Economic reform during the 1980 s accelerated agricultural growth and lifted farmers' incomes. Growth of farmers' incomes was, however, far slower than the rapid growth of the whole economy and urban income growth, especially in the 1990s, which resulted in larger rural-urban income disparities. Meanwhile, the rural population and labour force continued to account for the major part of China's total population and labour force, while the share of agricultural product in GDP fell.

\section{RURAL DEVELOPMENT AND RURAL-URBAN INCOME DISPARITY IN CHINA}

The agricultural sector (including farming, forestry, animal husbandry and fisheries) has experienced relatively fast growth since 1978, as compared with the pre-reform period: 4.8 per cent versus 2.7 per cent in terms of the average growth rate of valueadded (Table 13.1). In the reform period, development of the agricultural sector has solved the long-term problem of food shortages, rural incomes have increased substantially, and rural poverty has been reduced significantly.

In spite of the significant improvement in agricultural production, the agricultural sector's dominant role in the economy has been lost to the industrial and service sectors, due to rapid industrialisation during the past half century. The share of the 
agricultural sector in GDP declined from 51 per cent to only 14 per cent over the period 1952-2002. Meanwhile, because of its large share, and the continued growth of the rural population, the employment structure of the agricultural and nonagricultural sectors has changed far more slowly than the output structure. Agricultural employment accounted for 84 per cent of total employment in 1952, and 50 per cent in 2002. Over the same period, agricultural employment increased from 173 to 369 million. During the past half century, the share of the rural population in the national total has declined even more slowly: from 85 per cent in 1953 to 61 per cent in 2002 (Table 13.2). ${ }^{1}$

Agriculture remains the most important source of rural incomes (that is, as compared with the rural industrial sector, the services sector, and remittances of rural-urban migrants), but its importance has declined due to the significant changes in the production structure of the economy. Within agriculture, the share of farm

Table 13.1 Growth of the agricultural sector and rural population in the prereform and reform periods, 1952, 1978 and 2002

\begin{tabular}{lccc}
\hline & $\begin{array}{c}\text { Agricultural value-added } \\
\text { (billion Yuan) }\end{array}$ & $\begin{array}{c}\text { Agricultural worker } \\
\text { (million persons) }\end{array}$ & $\begin{array}{c}\text { Rural population } \\
\text { (million persons) }\end{array}$ \\
1952 & 34 & 173 & $505^{* *}$ \\
1978 & 68 & 283 & 790 \\
2002 & 209 & 369 & 782 \\
Growth 1953-78 & 2.7 per cent & 1.9 per cent & 1.8 per cent \\
Growth 1979-2002 & 4.8 per cent & 1.1 per cent & 0.0 per cent \\
\hline
\end{tabular}

Notes: *In 1952 constant prices, deflated by the Price Index of Agricultural Products. For the few years when the index is unavailable, the rural CPI is used instead. ${ }^{* *} 1953$ data.

Source: Calculated from National Bureau of Statistics, various years. Statistical Yearbook of China, Statistics Press, Beijing.

Table 13.2 Agricultural sector, share of GDP, employment and population, 1952-2002 (per cent)

\begin{tabular}{lccc}
\hline & GDP & Employment & Population \\
1952 & 51 & 84 & 85 \\
1978 & 28 & 70 & 82 \\
2002 & 14 & 50 & 61 \\
\hline
\end{tabular}

Source: Calculated from Table 13. 1 and National Bureau of Statistics, various years. Statistical Yearbook of China, Statistics Press, Beijing. 
income has also fallen (Table 13.3). Grain production remains the major farming activity, especially in less developed regions, although it is gradually being replaced by other farming activities.

During the pre-reform period-from the 1950s to the mid 1970s-movement of the agricultural population to non-agricultural sectors was hampered by the restrictive migration policies. However, rural industrialisation and urbanisation have increased since the adoption of market-oriented reforms. Such developments have provided close to 200 million additional non-agricultural jobs to rural workers in rural and urban areas over the past 24 years. Despite this, the number of farmers has increased, and there appears to be more surplus agricultural labour than ever.

Table 13.4 shows the changes in annual income per capita in rural and urban areas in the three regions (East, Centre and West) from 1980 to 2000. Rural income per capita was 47 per cent of urban income per capita in 1980. By 2000 , this ratio had fallen to 35 per cent. The rural-urban income disparity increased in all three regions, but most seriously in the least-developed West region, where the ruralurban income ratio fell from 45 to 30 per cent over this period. In 2000 , the average rural income per capita in the West region was 1713 Yuan (or US\$207), whereas the urban income in the region was 5642 Yuan.

\section{THE IMPACT OF DOMESTIC POLICIES AND INTERNATIONALISATION ON AGRICULTURE AND RURAL INCOMES}

Agricultural reform, begun in the late 1970s, broke the long-term stagnation in rural development and turned food shortages into surpluses. Grain production was initially stimulated by increases in state purchasing prices in 1979, and subsequently fuelled by the introduction of the Household Responsibility System in the early 1980s, which converted the collective-based production system into a household-based system. Between 1978 and 1984, grain output increased nearly 50 per cent.

However, grain production was never fully liberalised. It was subject to three prices at that time- the state quota and above-quota prices, and the market price. Market prices only played a role at the margin while the volume of state purchases remained large. Because of the rigidity of the controlled prices, the real prices of major grains fell significantly in the late 1980s, a period of high inflation (Wang 2001). As a result, output growth stagnated in the mid and late 1980s. In the early 1990s, however, grain output reached 440 million tons (compared with 400 million tons in the late 
Table 13.3 Agriculture as a source of rural income, 1990-2002 (per cent)

\begin{tabular}{lccc}
\hline & 1990 & 1995 & 2002 \\
Agr. share (rural income $=100$ per cent ) & 74 & 63 & 47 \\
Farming share (agr. output=100 per cent) & 65 & 58 & 55 \\
\hline
\end{tabular}

Source: NBS (National Bureau of Statistics), 2003. Statistical Abstract of China, Statistics Press, Beijing.

Table 13.4 Rural-urban income disparity, 1980 and 2000

(Chinese Yuan in current prices)

\begin{tabular}{lccccccc}
\hline & Urban & $\begin{array}{c}1980 \\
\text { Rural }\end{array}$ & $\begin{array}{c}\text { Rural/urban } \\
\text { (per cent) }\end{array}$ & Urban & $\begin{array}{c}2000 \\
\text { Rural Rural/urban } \\
\text { (per cent) }\end{array}$ \\
East & 452 & 246 & 54.4 & 7940 & 3429 & 43.2 \\
Center & 386 & 191 & 49.5 & 5217 & 2091 & 40.1 \\
West & 383 & 172 & 44.9 & 5642 & 1713 & 30.4 \\
China & 413 & 193 & 46.7 & 6635 & 2301 & 34.7 \\
\hline
\end{tabular}

Note: incomes are calculated by the authors as weighted averages from urban disposable income and rural pure income at the provincial level.

Source: NBS (National Bureau of Statistics), 2000a, 2001. Statistical Yearbook of China, Statistics Press, Beijing.

1980s), probably because above-quota prices had become more flexible and moved closer to market prices.

The government attempted to liberalise the quota control system in grain production in 1993, but the policy was abandoned due to the sudden increase in market prices and supply shortages resulting from hoarding behaviour due to expectations of price increases. In place of the price liberalisation, the government increased the quota prices substantially between 1994-97 and also introduced a 'provincial governor responsibility system' to ensure local self-sufficiency of grain supply.

Stimulated by these measures, grain output increased by 15 per cent between 1994-98 and reached a historical high of 512 million tons in 1998. This level exceeded domestic demand and resulted in falls in market prices. From 1996 to 2000, the market prices of rice, wheat, corn and soybeans fell by 39-44 per cent, and remained low in 2001-02. Analysis has shown that the inflexibility of the government pricing system has caused serious price and output instability in grain markets (Wang 2001). 
Low grain prices had a seriously negative impact on farmers' incomes, especially the incomes of famers who relied heavily on grain production. Faced with this problem, the government decided in 1998 to purchase all traded grains at above-market prices. To limit the government subsidy, it was also decided that the retail price should not be lower than the support price. To ensure this, grain markets were monopolised and private businesses were prohibited from purchasing grain from farmers.

This policy failed to protect farmers' incomes for several reasons. Most importantly, it was impossible to monopolise the already partially liberalised grain markets; therefore there was downward pressure on the purchase prices. Second, the role of policy executants given to the state grain companies conflicted with their role as profit makers. To make profits or avoid losses, they tended to undergrade the quality of the grain they were purchasing to avoid paying anything more than market prices. This system also resulted in rent-seeking behaviour by the state grain agents. Finally, even if consumer prices could be monopolised, demand for grain cannot be controlled by the state and any surplus grain could not be sold. As a result, either the state or farmers had to bear the ensuing huge losses.

As a result of these problems, grain markets were re-opened in eight east coast provinces in 2001-02. In 2003, the central government conducted an experiment in some areas, paying the margin between the market price and the support price directly to farmers as a lump sum, and liberalised the local grain market at the same time. However, the support price system remains in a number of provinces. This policy is in conflict with the liberalisation of imports resulting from China's accession to the WTO.

China entered the WTO in 2001 and made a commitment to open its food markets substantially. The average tariff rate for all agricultural products was reduced from 22 per cent to 17.5 per cent. Export subsidies on agricultural products were eliminated, and China accepted a tariff rate quota (TRQ) for imports of major grains at a tariff rate of 1 per cent. The quota was set at 18 million tons for 2002, increasing to 22 million tons by 2004. Any unused quota of the state trading companies is to be transferred to non-state trading companies. This means that once domestic prices exceed international prices, the quota will be usedautomatically, which will reduce price levels. The tariff rate for soybeans is only 3 per cent and there is no quota (WTO 2001).

The import quota is large compared with the historical level of imports. In the 1990 s, the average annual level of grain imports was nine million tons. Given that 
half of all grain output is consumed by farmers and does not enter the formal market, the size of the domestic grain market is about half of the total output. Therefore, the 2004 TRQ accounts for 11.9 per cent of the domestic grain market. It is estimated that full utilisation of the TRQ in the short run-that is, without the full working through of the adjustment to any price changes-could mean the loss of nine million farming jobs; or alternatively, it implies a significant decline in grain farmers' incomes (Wang 2002).

In 2001 and 2002, grain imports (including soybeans) totalled 17.4 and 14.2 million tons. These large imports prevented domestic grain prices from recovering their previous levels. Grain output fell from the 1999 level of 508 million tons to 462 and 453 million tons in 2001 and 2002 respectively. Clearly, without adjustments in the agricultural sector, increased grain imports will adversely affect farmers' incomes and widen the rural-urban income gap.

The WTO accession commitments provide great opportunities for reforming China's agricultural sector, which could lead to positive long-run impacts on farmers' incomes. The liberalisation should push agricultural activity towards China's comparative advantages, leading to higher efficiency. For example, in 2002 the area sown to grain fell by 2 per cent but grain output increased by 1 per cent. New breeds of soybean with higher quality and higher oil content were introduced (CCTV 2003). Output of other agricultural products increased significantly. Sugarcane and beetroots together increased by 16 million tons in 2002, a 19 per cent increase over the 2001 level. Tea and fruit production increased by 6 per cent and 4 per cent respectively. These developments indicate that further increases in efficiency in agricultural production are possible in response to the WTO challenge.

Although grain market deregulation and structural adjustment in the agricultural sector are important, more is needed to reduce the rural-urban income disparity significantly. Given the huge labour surplus in the agricultural sector, further policy adjustments are needed in order to accelerate the transfer of the redundant agricultural labour force to non-agricultural rural and urban sectors.

\section{RELATIONSHIPS BETWEEN RURAL INDUSTRIALISATION AND URBANISATION AND RURAL INCOMES}

During the economic reform period, particularly in the 1980s and early 1990s, dramatic developments occurred in the rural industrial sector (the township and village enterprise (TVE) sector) that made a major contribution to China's rapid 
economic growth (see World Bank 1996; Cai et al. 2000; Wang 2000). Employment in the TVE sector increased from 28 million to 135 million during 1978-96, accounting for more than one-quarter of the total rural labour force. TVEs produce at least onequarter of total industrial output. In the earlier period, most TVEs were collectively owned. Most TVEs have been privatised since the 1990s.

Development of the rural industrial and services sectors also made a great contribution to increases in farmers' incomes. Nearly half of all rural household income now comes from the industrial and services sectors. Figure 13.1 shows clearly that the level of rural income per capita in China's 31 provinces is closely related to provincial achievements in rural industrialisation (as indicated by the share of TVE employment in the rural labour force).

Rural industries experienced substantial growth in the 1980s, partly because the rural reform created a better market environment while the urban economy was still

Figure 13.1 Relationship between rural industrialisation and rural income, 2000

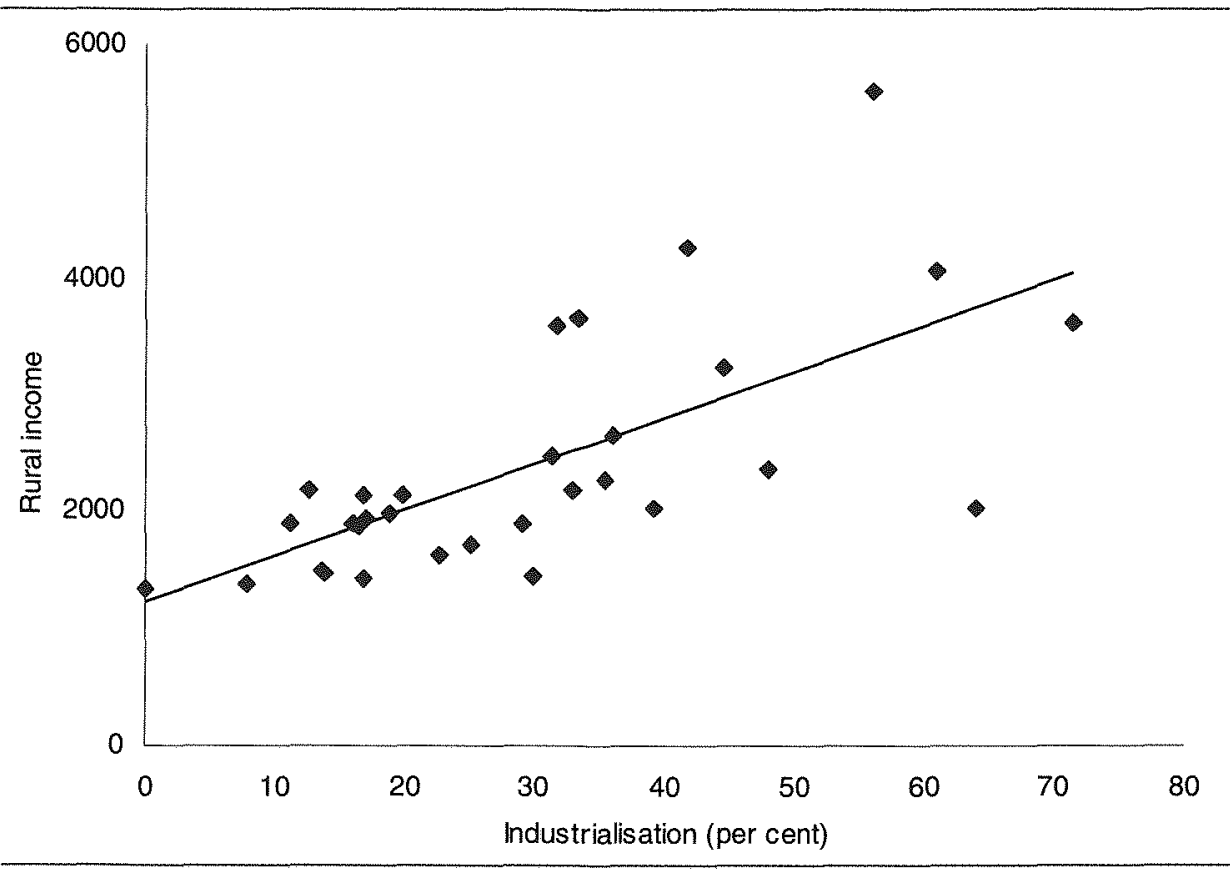

Note: Rural industrialisation is indicated by the share of TVE employment in rural labour, and rural income is defined as per capita rural pure income (yuan).

Source: Calculated from NBS (2000a, 2001). 
heavily subject to central control. Government policies also had an important influence during this period, encouraging development of TVEs in rural areas and discouraging rural-urban migration.

Development of rural industries slowed in the late 1990s, mainly due to sharper market competition, the unfavourable location of rural enterprises, difficulties in accessing external finance, and lack of infrastructure facilities, technical inputs, and human resources. Meanwhile, urbanisation accelerated. Large numbers of rural labourers migrated to urban areas in search of jobs. In 2001, the urbanisation rate (the ratio of urban to total population) in China reached 38 per cent, compared to 26 per cent in 1990 and 19 per cent in 1980. Increased availability of rural finance would help the development of rural industries. Nevertheless, the importance of rural industrialisation in the economy is likely to be replaced by urbanisation.

In spite of the acceleration of urban development, the urbanisation rate in China is on average 10-20 percentage points lower than in other countries at a similar income level (Wang and Xia 1999). In particular, there are relatively few medium and large cities given China's large population. In 2000, 121 million people, only 9.6 per cent of the national population, lived in cities of more than 0.5 million people. In the lessdeveloped West region, only 5.6 per cent of the population lived in cities of that size. If China had an urbanisation rate similar to that of other countries at the same income level, an additional 120-240 million people would be living in urban areas. ${ }^{2}$ This number may also be thought of as the excess supply of people in the rural economy.

The urbanisation rate and rural income of China's 31 provinces in 2000 suggests a positive relationship between rural income and urbanisation: provinces with a higher urbanisation rate have a higher rural income (Figure 13.2). This relationship may imply that urbanisation helps to liberate redundant rural labour from arable land and therefore increase agricultural productivity. Considering that half the Chinese labour force is still engaged in agricultural labour, further urbanisation is likely to have a significant impact on agricultural productivity.

\section{A CAUSALITY TEST ON THE IMPACT OF URBANISATION AND POLICY CONSIDERATIONS}

Urbanisation need not be the only explanation for the relationship (Figure 13.2); both urbanisation and higher rural incomes can be an outcome of economic growth. In the following, we introduce a growth model to test the causality between urbanisation and regional economic growth. This model has its origins in neoclassical growth 
models and endogenous growth models (see, for example, Solow 1956; Lucas 1988) but includes additional variables representing urbanisation.

$$
Y_{i t}=A+a^{7} K_{i t}+a^{2} H_{i t}+a^{3} D_{n i t}+a^{4} L+a^{5} U_{i t-1}+a^{6} D U_{i(t-1)}+\mu_{i t}
$$

where $Y_{i t^{t}} K_{i t^{t}} H_{i t^{t}} D_{i t}$ and $L_{i t}$ are growth rates of GDP, capital stock, human resources (indicated by workers' average years of schooling), cultivated land area and total employment, respectively, of the ith province in year $t . U_{i t-1}$ is the urbanisation rate with a one-year lag (the urbanisation rate used is the ratio of urban employment to provincial total employment). $D U_{i(t-1)}$ is the difference in $U_{i}$ between years $t-1$ and $t-$ 2. $\mu$ is the error term.

Lagged variables of $U$ and $D U$ are used for the causality test between urbanisation and economic growth. This specification identifies the effect of urbanisation on growth if either $U_{i t-1}$ or $D U_{i t-1}$ is positive and significant. Both $U_{i t-1}$ and $D U_{i t-1}$ are included in the model to distinguish between the possible growth effect (long-run effect) and the level effect (short-run effect) of urbanisation. A significant estimate of $U_{i t-1}$ indicates a continuing effect of urbanisation on growth (meaning that a higher urbanisation rate brings about higher productivity growth), whereas a significant estimate of $D U_{t-1}$ indicates an impact from changes in the urbanisation rate on growth, which is a short-run effect.

To impose the restriction of constant returns to scale $\left(a^{3}=1-a^{1}-a^{2}\right)$, both sides of Equation 13.1 were divided by $L_{t^{\prime}}$

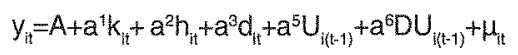

where $y, k, h$ and $d$ are $Y, K, H$ and $D$ divided by $L$, respectively.

To see the possible differences in the urbanisation effect at the different levels of economic development, $U_{i(t-1)}$ is replaced by three urbanisation variables for the East, Central and West regions in version 2 of the model. The East region is the most developed while the West region is the least developed of the three regions. Similarly, replacements are made to $D U_{i(t-1)^{\prime}}$.

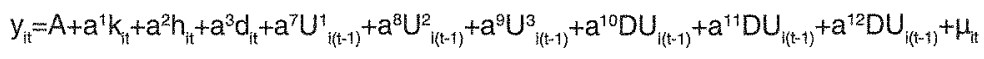

Panel data for 25 provinces covering the 20 years from 1979 to 1998 were used. The other six provinces were excluded due to incomplete data. Data were provided by Fang Cai and Dewen Wang (forthcoming) and the National Bureau of Statistics (StatisticalYearbook of China (various years) and 1999b). Capital stock was calculated from the historical data for capital formation in each province. 
Both fixed effects and random effects models were estimated. Hausman's test rejects the hypothesis that the random effects model is appropriate, therefore the results of the fixed eeffects model are reported in Table 13.5.

The two versions of the model produce similar results. Most coefficients are statistically significant at the 1 per cent level. According to version (13.1'), the elasticities of capital, human resources, employment and land with respect to economic growth are $0.348,0.431,0.205$ and 0.016 respectively, all in reasonable ranges. The elasticity of land is minor and insignificant, which is not surprising because the farming sector now contributes such a small share of total GDP and increased yields account for all of China's growth in agricultural output. The estimates of urbanisation $(U)$ are positive and significant. This result indicates that each percentage point increase in the urbanisation rate accelerates provincial economic

Figure 13.2 Relationship between urbanisation and rural household income, 2000

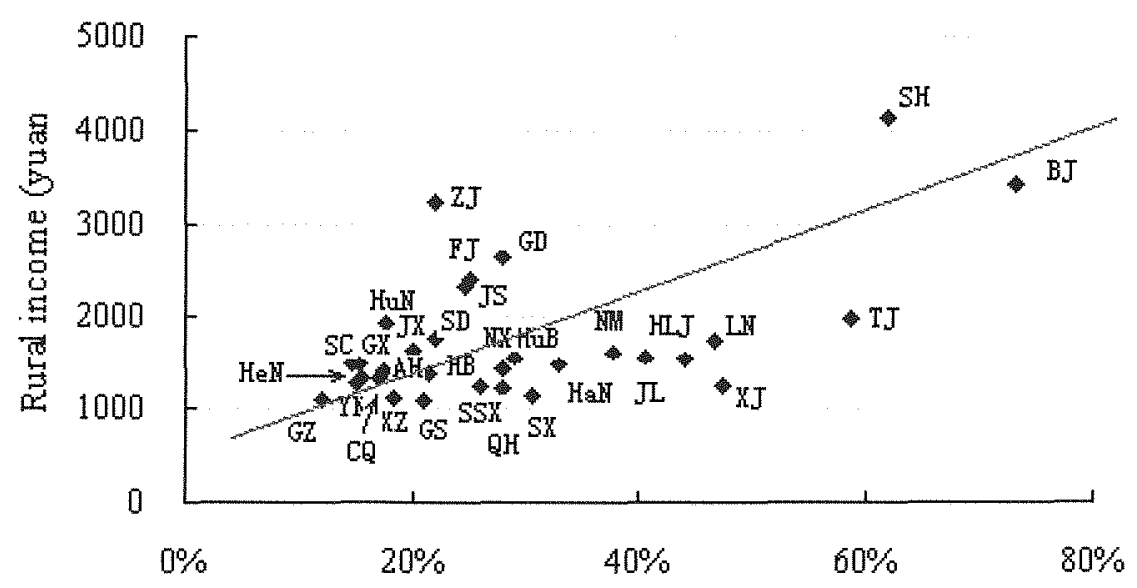

Urbanization rate

Note: The urbanisation rate used in this figure is the proportion of urban to total employment in each province. Symbols of provinces-BJ: Beijing, TJ: Tianin, HB: Hebei, SX: Shanxi, NM:

Neimenggu, LN: Liaoning, JL: Jilin, HLJ: Heilongjiang, SH: Shanghai, JS: Jiangsu, ZJ: Zhejiang, AH: Anhui, FJ: Fujian, JX: Jiangxi, SD: Shandong, HeN: Henan, HuB: Hubei, HuN: Hunan, GD:

Guangdong, GX: Guangxi, HaN: Nainan, CQ: Chongqing, SC: Sichuan, GZ: Quizhou, YN: Yunnan, XZ: Xizang, SnX: Shannxi, GS: Gansu, QH: Qinghai, NX: Ningxia, XJ: Xinjiang

Source: National Bureau of Statistics, 2001. Statistical Yearbook of China, Statistics Press, Beijing. 
growth by 0.37 percentage points over the already high 7-10 per cent growth rate. $D U$ is omitted from the model due to insignificant estimates in previous regressions. These results suggest that urbanisation has a long-run impact on economic growth.

For version 2, the results suggest a significant effect of urbanisation on economic growth in both the East and Central regions, but the effect is minor and insignificant for the less-developed West region. There may be two possible reasons for the latter result: the rate of urbanisation in the West has been low, and the urban economy in the West provinces, unlike the other regions, has not experienced much restructuring, and is therefore less market-oriented and less efficient.

In general, the results identify a contribution of urbanisation to economic growth via productivity changes. This implies that reallocating resources from rural to urban economies can result in higher growth rates in the productivity of the resources being reallocated. In addition, because this reallocation reduces the surplus labour in the rural sector, it can increase the productivity of the remaining rural labour and reduce the rural-urban income gap. Theoretically, this result would follow from an assumption of diminishing marginal product of labour in the rural sector.

The fact that urbanisation in China lags so far behind other countries is mainly a result of earlier central government policies restricting rural-urban migration and the growth of cities. Some of these restrictions have been removed over the past decade, but rural-urban migration is still partially restricted by the urban household registration

Table 13.5 Modelling results: urbanisation and economic growth

\begin{tabular}{lcccc}
\hline & \multicolumn{2}{c}{ Version $1^{\prime}$} & \multicolumn{2}{c}{ Version 2} \\
Variable & Coefficient & t-ratio & Coefficient & t-ratio \\
$\mathrm{k}$ & 0.3481 & $\left(8.891^{* *}\right)$ & 0.3552 & $\left(8.931^{* *}\right)$ \\
$\mathrm{h}$ & 0.4315 & $\left(5.122^{* *}\right)$ & 0.4261 & $\left(5.045^{* *}\right)$ \\
$\mathrm{d}$ & 0.0157 & $(0.903)$ & 0.0159 & $(0.911)$ \\
$\mathrm{U}_{\mathrm{t}-1}$ & 0.3753 & $\left(3.619^{* *}\right)$ & & \\
$\mathrm{U}^{1}$ & & & 0.3560 & $\left(2.698^{* *}\right)$ \\
$\mathrm{U}^{2}$ & & & 0.5525 & $\left(2.835^{* *}\right)$ \\
$\mathrm{U}^{3}$ & & & 0.0097 & $(0.031)$ \\
$\mathrm{Constant}^{*}$ & -0.0837 & $\left(-2.383^{*}\right)$ & -0.2119 & $\left(-2.265^{*}\right)$ \\
& Dependent var. & $\mathrm{y}$ & Dependent var. & $\mathrm{y}$ \\
& $\mathrm{R}^{2}$ & 0.3697 & $\mathrm{R}^{2}$ & 0.3726 \\
\hline
\end{tabular}

Note: $t$ ratios with * and ${ }^{* *}$ are significant at the 5 per cent and 1 per cent levels, respectively. Source: Estimation result. Original data are from NBS $(2001,1999 \mathrm{~b})$. 
system, job entry barriers, and non-access or harder access to services such as housing, schooling, health care benefits, and public security protection for rural migrants. The low level, or lack of, rural education, job training, and employment information services are also barriers to rural-urban migration. Policy changes to remove these restrictions, to improve rural education, and to provide government services in job training and employment information services are essential for accelerating urbanisation.

The current urban economies provide limited opportunities for rural migrants because the number of cities is limited, and their average size small. Expansion of the urban economy will provide more employment opportunities, especially in China's underdeveloped services sector, which accounts for a significantly higher percentage of GDP in the urban sector than the rural sector. It is the government's responsibility to improve urban planning and to provide urban infrastructure and public utilities in order to promote urban development. With these changes, many small cities and towns can be expected to become large or medium sized cities.

\section{CONCLUSION}

While China has experienced rapid economic growth in the reform period, rural incomes have grown slowly in recent years and the rural-urban income gap is growing. This outcome has been partly due to the non-market-oriented agricultural policies of the 1990s. WTO accession commitments have added new challenges for the rural economy and for agricultural policymaking. Reforms to liberalise the agricultural pricing system and promote market-oriented adjustment of the agricultural structure are essential, although they are not sufficient to yield significant reductions of the rural-urban income disparity.

The agricultural sector in China is seen as being labour-redundant, largely as the result of policies restricting the development of urban areas. These policies are also seen as a major reason for China's large and growing rural-urban income gap.

The urbanisation rate in China is far lower than in other countries at a similar level of GDP per capita. Our findings indicate that urbanisation has positive and significant effects on rural incomes and regional economic growth. Therefore, we recommend that urbanisation should be accelerated by deregulating rural-urban migration, developing urban infrastructure, improving rural education, job training, and enhancing the provision of employment information services. 


\section{NOTES}

1 Data used in this paper are from the National Bureau of Statistics (various years) unless otherwise noted

2 These calculations take into account estimates of the so-called 'floating population' that is living in urban areas but is still registered as rural.

\section{REFERENCES}

Cai Fang, Dewen Wang and Juwei Zhang, 2000. 'Economic growth in China: labour, human capital and employment structure', in Xiaolu Wang and Gang Fan (eds), The Sustainability of China's Economic Growth, Economic Science Press, Beijing. Cai Fang and Dewen Wang, forthcoming. 'Regional comparative advantage in China: differences, changes and its impact on regional disparity', in Xiaolu Wang and Gang Fan (eds), Regional Disparity in China: changing trends and influential factors, Economic Science Press, Beijing.

Lucas, R.E., 1988. 'On the mechanics of economic development', Journal of Monetary Economics, 22(1):3-42.

Ministry of Agriculture, various years. China Agricultural Development Report, Ministry of Agriculture, Beijing.

National Bureau of Statistics, various years. Statistical Yearbook of China, Statistics Press, Beijing.

- 2003. Statistical Abstract of China, Statistics Press, Beijing.

- 1999. Comprehensive Statistical Data and Materials on 50 years of New China, China Statistics Press, Beijing.

Solow, R.M., 1956. 'A contribution to the theory of economic growth', Quarterly Journal of Economics, 70(1):65-94.

Wang Xiaolu, 2000. 'The role of rural industrialization in China's economic growth', in Xiaolu Wang and Gang Fan (eds), The Sustainability of China's Economic Growth, Economic Science Press, Beijing.

2001. Grain Market Fluctuations and Government Intervention in China, Research Report for the ACIAR project 'China's Grain Market Policy Reform', The Australian National University, Canberra.

- 2002. 'The WTO challenge to agriculture', in R. Garnaut and L. Song (eds), China 2002: WTO entry and world recession, Asia Pacific Press, The Australian National University, Canberra:81-96. 
— and Xiaolin Xia, 1999. 'Optimum city size and economic growth', Economic Research, 9.

World Bank, 1996. The Chinese Economy: controlling inflation, deepening reform, World Bank, Washington, DC.

WTO (World Trade Organization), 2001. 'Accession of the People's Republic of China, Decision of 10 November 2001', World Trade Organization, Washington, DC. Available online at www.wto.org. 